\title{
Extent of Primary Breast Cancer Surgery: Standards and Individualized Concepts
}

\author{
Joerg Heil ${ }^{a}$ Valerie Fuchs ${ }^{a}$ Michael Golatta ${ }^{a}$ Sarah Schott ${ }^{a} \quad$ Markus Wallwiener $^{a}$ \\ Christoph Domschke ${ }^{\mathrm{a}}$ Peter Sinn ${ }^{\mathrm{b}} \quad$ Michael P. Lux $^{\mathrm{c}}$ Christof Sohn ${ }^{\mathrm{a}} \quad$ Florian Schütz $^{\mathrm{a}}$ \\ aUniversitäts-Frauenklinik, Universitätsklinikum Heidelberg, \\ bInstitut für Pathologie, Universität Heidelberg, \\ 'Universitäts-Brustzentrum Franken, Frauenklinik, Universitätsklinikum Erlangen, Germany
}

\section{Keywords}

Breast cancer surgery · Resection margins .

Sentinel lymph node biopsy · Axillary lymphonodectomy

\section{Summary}

Surgery is still a main therapeutic option in breast cancer treatment. Nowadays, methods of resection and reconstruction vary according to different tumors and patients. This review presents and discusses standards of care and arising questions on how radical primary breast cancer surgery should be according to different clinical situations. In most early breast cancer patients, breast conservation is the method of choice. The discussion on resection margins is still controversial as different studies show conflicting results. Modified radical mastectomy is the standard in locally advanced breast cancer patients, although there are different promising approaches to spare skin or even the nipple-areola complex. A sentinel node biopsy is the standard of care in clinically node-negative invasive breast cancer patients, whereas the significance of axillary lymphonodectomy seems to be questioned through a number of different findings. Although there are interesting findings to modify surgical approaches in very young or elderly breast cancer patients, it will always be an individualized approach if we do not adhere to current guidelines. Up to date, there are no special surgical procedures in BRCA mutation carriers or patients of high-risk families.

\author{
Schlüsselwörter \\ Operative Mammakarzinomtherapie · Resektions- \\ grenzen · Wächterlymphknotentechnik · Axilläre \\ Lymphonodektomie
}

\section{Zusammenfassung}

Die Operation des Mammakarzinoms ist nach wie vor ein zentraler Therapieansatz. Heutzutage variieren Herangehensweisen der Resektion und Rekonstruktion je nach Tumor und Patientin erheblich. Diese Literaturzusammenstellung stellt den aktuellen Wissensstand dar und diskutiert aufkommende Fragen, wie ausgedehnt die operative Therapie des Mammakarzinoms in verschiedenen klinischen Situationen sein sollte. Die Brusterhaltung ist beim frühen Mammakarzinom heute die Methode der Wahl. Die Diskussion über Resektionsgrenzen wird nach wie vor kontrovers geführt, da verschiedene Studien widersprüchliche Ergebnisse zeigen. Die modifiziert radikale Mastektomie ist der Standard bei der Behandlung des fortgeschrittenen Mammakarzinoms, wobei es hier sehr vielversprechende Ansätze der weiteren Reduzierung der Radikalität (Haut-, Areolen- und Nippelerhalt) gibt. Die Entfernung des Wächterlymphknotens kommt beim klinisch nodal negativen, invasiven Mammakarzinom heute in vielen Situationen zum Einsatz, wohingegen die Bedeutung der axillären Lymphonodektomie durch eine Reihe von ähnlichen Studienergebnissen infrage gestellt wird. Obwohl verschiedene Studienergebnisse den Schluss nahelegen, bei sehr jungen oder älteren Patientinnen individualisierte Konzepte zu verfolgen, bleibt es bisher bei Einzelfallentscheidungen. Für BRCA-Mutationsträgerinnen und Patientinnen aus Hochrisikofamilien gibt es bislang keine besonderen operativen Empfehlungen.

\section{KARGER \\ Fax +497614520714 \\ Information@Karger.de}

www.karger.com (c) 2012 S. Karger GmbH, Freiburg

$1661-3791 / 12 / 0075-0364 \$ 38.00 / 0$

Accessible online at:

www.karger.com/brc 


\section{Introduction}

Breast cancer surgery is still a main therapeutic option in breast cancer treatment. Meanwhile, methods of resection and reconstruction vary according to different tumors and patients. The goals of breast cancer surgery in combination with all other treatment efforts remain the same: amelioration of (disease-free) survival and quality of life. In line with efforts to individualize systemic treatment, one even might discuss individual surgical approaches in specific situations. Do we need to perform or especially recommend to the patient the same surgical procedures regardless of age, medical history, family history, or tumor biology? Surgeons and patients might be interested in individualized surgical concepts.

This review will present and discuss standards of care and arising questions on how radical primary breast cancer surgery should be according to different clinical/patient situations.

\section{Review of the Literature and Discussion}

\section{Early Breast Cancer}

During the last century, breast cancer surgery has become less radical, starting with radical mastectomy [1] through modified radical mastectomy (MRM) to breast-conserving surgery (BCS) [2]. BCS with subsequent radiotherapy has proven to be equivalent to MRM alone with respect to survival [3, 4]. Since then, we may therefore conclude that BCS is the standard of care for patients with early breast cancer - in cases where it is technically feasible.

The aim of tumor-free resection margins (R0) has to be achieved $[5,6]$ because margin status is an important risk factor for local recurrence [7-10]. The optimal margin width is unclear up to now $[7,11,12]$. With respect to local recurrences, margins $>1 \mathrm{~mm}$ seem not necessarily to be more secure than margins of $1 \mathrm{~mm}$ in invasive tumors [13-16]. Even clear margins do not guarantee complete excision, because positive reexcisions are even found in $21 \%$ of cases with initially negative margins [17]. In invasive cancers with extensive intraductal component (EIC), there are also studies proposing a safety distance of $\geq 5 \mathrm{~mm}$ [18]. On the other hand, we may adapt these aims according to topographic circumstances; e.g., when performing segmental resection up to the pectoralis fascia, margins may be less in direction to the pectoralis fascia and in relation to neighboring skin [19]. With respect to resection margins in ductal carcinoma in situ (DCIS) only cases, there is a consensus that $2 \mathrm{~mm}$ should be achieved $[19,20]$ if a radiation therapy will be applied. A recent meta-analysis even favors more radical resection margins [21] on the basis of less long-term local recurrences, even in cases with radiation therapy. In summary, the current guidelines propose a margin width of $1 \mathrm{~mm}$ in invasive cancers (regardless of an accompanying in situ component) and $2 \mathrm{~mm}$ in DCIS only cancers [22].

\section{Locally Advanced Breast Cancer}

In locally advanced breast cancer - meaning large tumors (absolute and relative to breast size), tumors infiltrating the pectoralis muscle or even the thoracic wall (intercostal muscles), and skin involvement - one may consider more radical approaches. Standard of care is the MRM [23, 24]. There are no randomized controlled trials comparing MRM with skinsparing or even nipple-sparing approaches. Nevertheless, these techniques may be applied in selected situations and will probably not impair the oncological security [25]. It is difficult to properly define these selected situations because different studies reported on different surgical techniques ('subcutaneous' mastectomy with more subcutaneous tissue left behind the skin, skin-sparing or even nipple-sparing with or without intraoperative radiation, etc.). A rational approach might be to at least adhere to minimal resection margins as stated above (1 mm invasive, $2 \mathrm{~mm}$ DCIS).

Primary systemic treatment should be considered in locally advanced breast cancer. Even in these situations, complete tumor resection (i.e. tumor-free resection margins) is necessary. In the majority of cases, mastectomy is needed. For appropriately selected patients whose tumors show adequate downstaging after primary chemotherapy, breast preservation appears to be feasible and oncologically secure [26-30].

There is little information on inflammatory breast cancer (IBC) alone. It is defined as clinical signs of affected skin of $>1 / 3$ of the breast involved (previous definition $>2 / 3$ of the breast) [31]. Most retrospective analyses focus on T4 carcinomas without separating T4d cancers. IBC might be a distinct biological entity. Prospective randomized trials for the diagnosis and treatment of patients suffering from IBC are still missing.

\section{Management of Axillary Lymph Nodes}

One aspect of the surgical approach in patients with invasive breast cancer is determination of the histological lymph node status $(\mathrm{pN})$. Nowadays, this is mainly reached by removing the sentinel node(s) [32-34]. In invasive breast cancer, sentinel lymph node biopsy (SNB) is the standard of care in patients without clinical or imaging signs of nodal involvement $[35,36]$. SNB is equal to dissection of the whole axilla concerning all oncological outcome measures (beginning with local control to overall survival (OS)), but morbidity is reduced significantly by performance of SNB [34, 37-42]. Contraindications are clinical suspicion of advanced lymph node involvement and positive lymph nodes, as well as after neoadjuvant chemotherapy, particularly if lymph nodes are suspicious before chemotherapy $[32,33]$. In case of neoadjuvant chemotherapy, the results of the SENTINA trial will perhaps change the clinical practice [43]. SNB can also be performed to reliably predict the nodal status in multicentric carcinomas, shown by functional studies of the patterns of lymph drainage and initial clinical data; however, empirical evidence is limited [44-47]. 
In cases of 1 or 2 metastases in sentinel lymph nodes, it is unclear if these patients will benefit from performing a secondary axillary lymphonodectomy - provided that BCS was performed, no suspicious lymph nodes were found pre- and intraoperatively and that tangential whole breast irradiation will be applied [48]. In the referred ACOSOG Z0011 trial, no subgroup was found to benefit from a secondary lymphonodectomy; however, one has to take into account the short follow-up period and the small patient groups.

In patients with clinical nodal involvement, surgical removal of axillary lymph nodes is still indicated because the amount of positive nodes might be relevant for systemic and radiation therapy decisions. There might also be minimally better local control of complete axillary dissection compared with radiation alone. In some special cases, only radiotherapy may be performed, e.g., if there is no information needed for the decision on systemic therapy or if the patient is very old [49-51]. In patients with tumors with microinvasion or very old patients, one may consider giving up all axillary intervention $[49,52,53]$. In case of distant metastasis, axillary staging is not reasonable.

An axillary dissection in DCIS patients should not be applied; even an SNB should only be performed in mastectomy procedures or tumor resection near the axilla. In these cases, a secondary sentinel node biopsy is not technically feasible $[36,54]$. In cases in which tumor invasion is assumed, an SNB may be performed $[55,56]$ to avoid a secondary surgical procedure.

\section{Breast Cancer in Young Patients}

Young age (mostly defined as age at first diagnosis $\leq 35$ years) seems to be an independent risk factor for local recurrence and even OS [8,10,16, 57-59], even if the latter (effect of age on breast cancer survival) is still a matter of controversy. When adjusting for all prognostic variables, age was not significantly related to mortality from breast cancer with a hazard ratio (HR) of 0.8 (95\% confidence interval (CI): $0.3-2.0)$ for very young and 1.1 (95\% CI: $0.8-1.4)$ for young patients compared to older women [60]. Nevertheless largescale genomic analyses propose that breast cancer in young women might be a unique biologic entity driven by unifying oncogenic signaling pathways and characterized by less hormone sensitivity and higher HER2 expression [61]. Young breast cancer patients are more likely to experience ipsilateral breast tumor recurrence (IBTR) after BCS. This difference is seen mainly among women with HER2 subtype. Based on these findings, more aggressive efforts to achieve local and systemic control might be considered for young women with HER2-subtype breast cancer [62].

\section{Breast Cancer in Elderly Patients}

In aging societies, breast cancer in older patients is an important topic. Recently, the International Society of Geriatric Oncology (SIOG) and the European Society of Breast Cancer
Specialists (EUSOMA) updated their recommendations on screening, primary endocrine therapy, surgery, radiotherapy, neoadjuvant and adjuvant systemic therapy, and metastatic breast cancer in elderly patients [63]. In different studies, age has been described as an independent risk factor for non-receipt of effective cancer therapies, even when comorbidity and risk of recurrence are taken into account. After adjustment for comorbidity score, race, marital status, educational status, clinical stage, and tumor characteristics, increasing patient age was independently associated with decreased guideline concordance for definitive surgery, adjuvant chemotherapy, and adjuvant hormonal therapy [64]. The findings of the NORA (National Oncological Research observatory on Adjuvant therapy in breast cancer) study that indicate that age is significantly related to later diagnosis and different, less efficient patterns of treatment may help to change attitudes that currently exclude a significant proportion of breast cancer patients from secondary prevention policies, more active treatment strategies, and clinical research trials based on age [65].

Information regarding treatment effectiveness in this age group and tools that allow physicians and patients to estimate the benefits versus the risks of therapies, taking into account age and comorbidity burden, are critically needed [66]. Treatments need to be adapted to the patient's health status, but should also offer the best chance of cure [67].

Nonetheless, some data suggest adapted approaches in elderly breast cancer patients:

Some years ago a Cochrane review on the topic 'surgery and endocrine therapy in older women' was published. The published literature comparing surgery, with or without adjuvant endocrine therapy, with endocrine therapy alone in older women with operable breast cancer was systematically reviewed. When surgery alone was compared to endocrine therapy alone, there was no significant difference in OS (HR 0.98, $95 \%$ CI $0.74-1.30, p=0.9)$, but a significant difference was found in progression-free survival (PFS) (HR 0.55, 95\% CI $0.39-0.77, \mathrm{p}=0.0006)$. When surgery with adjuvant endocrine therapy was compared to endocrine therapy alone, there was no significant difference in OS (HR 0.86, 95\% CI 0.73-1.00, $\mathrm{p}=0.06$ ), but a significant difference was found in PFS (HR $0.65,95 \%$ CI $0.53-0.81, p=0.0001$ ) for surgery plus endocrine therapy versus primary endocrine. Primary endocrine therapy with tamoxifen has been associated with inferior local disease control but non-inferior survival to surgery for breast cancer in older women [68].

With respect to older patients, the current data increasingly suggest that operation of the axilla could be avoided in cases of small tumors and a clinically negative axilla [69]. Martelli et al. [69] presented the update of a study including 671 patients $\geq 70$ years ( 172 with axillary dissection and 499 patients without an operation of the axilla) at a median follow-up time interval of 15 years. There was no significant difference in mortality within this group in the case of pT1 cN0 disease ( $10.7 \%$ vs. $10.7 \%, p=0.836)$. Another study concluded that 
avoiding axillary clearance for women $\geq 60$ years who have clinically node-negative disease and receive tamoxifen for endocrine-responsive disease yields similar efficacy, with better early quality of life [53].

\section{Breast Cancer in BRCA Mutation Carriers or Family History of Breast Cancers}

In about $5-10 \%$ of breast cancer patients, we assume a genetic disposition; woman with germ-line mutations in BRCA1 or BRCA2 have a lifetime risk of $50-80 \%$ of developing breast cancer, a $30-40 \%$ risk of cancer in the contralateral breast after breast cancer, and a $10-40 \%$ risk of developing ovarian carcinoma [70-74]. Up to date, there is no special therapeutical recommendation for these cases of obvious family history; therapy therefore follows guidelines for sporadic breast cancer. Nevertheless, prophylactic mastectomy of the second breast can be considered to reduce the risk of second contralateral carcinoma, but there seems to be no benefit with respect to improved OS [74-76].

Also bilateral oophorectomy can be performed to reduce the risk of a second carcinoma of ovaries and breast, but there is also no evidence for advantage in terms of survival [72]. On the other hand, there is some evidence in women with stage I or II carcinoma of the breast that a survival advantage might be possible through the reduced incidence of ovarian carcinoma after bilateral oophorectomy [77].

Incidence of metachronic ipsilateral breast cancer recurrence does not seem to be higher, so breast-conserving therapy is an adequate procedure if the woman does not want mastectomy [73]. Some studies have shown a lowered incidence and mortality of BRCA-associated cancers if prophylactic bilateral mastectomy was done $[75,76]$, but probably without effects on OS [78].

\section{'Targeted' Breast Cancer Surgery}

As already implied above, there are some ideas to further individualize breast cancer surgery according to patient- and tumor-related factors. Unfortunately, there is still a gap between explorative, hypothesis-generating studies and confirmative trials to justify or falsify these approaches. Well-designed and -conducted surgical trials are necessary.

\section{Conclusions}

Breast cancer surgery is still a main therapeutic option in breast cancer treatment. Meanwhile, methods of resection and reconstruction vary according to different tumors and patients.

In most early breast cancer patients, breast conservation is the method of choice. The discussion on resection margins is still controversial and the results of many studies show conflicting results. MRM is the standard in locally advanced breast cancer patients, although there are different promising approaches to spare skin or even the areola, or even the whole nipple-areola complex. A sentinel node biopsy is the standard of care in clinically node-negative invasive breast cancer patients, whereas the significance of axillary lymphonodectomy seems to be questioned through a number of different findings. Although there are interesting findings to modify surgical approaches in very young or elderly breast cancer patients, it will always be an individualized approach if we do not adhere to current guidelines. Up to date, there are no special surgical procedures in BRCA mutation carriers or patients of high-risk families because the performed surgeries (mastectomy instead of breast conservation, contralateral prophylactic mastectomy, and bilateral salpingoovarectomy) improve local control but probably not OS.

\section{Disclosure Statement}

The authors declare no conflict of interest.

\section{References}

1 Halsted WS: I. The results of radical operations for the cure of carcinoma of the breast. Ann Surg 1907;46:1-19.

2 Donegan WL, Sugarbaker ED, Handley RS, Watson FR: The management of primary operable breast cancer. A comparison of time-mortality factors after standard, extended, and modified radical mastectomy. Proc Natl Cancer Conf 1970;6:135143.

>3 Fisher B, Anderson S, Bryant J, Margolese RG Deutsch M, Fisher ER, Jeong JH, Wolmark N: Twenty-year follow-up of a randomized trial comparing total mastectomy, lumpectomy, and lumpectomy plus irradiation for the treatment of invasive breast cancer. N Engl J Med 2002;347:1233-1241.

4 Veronesi U, Cascinelli N, Mariani L, Greco M, Saccozzi R, Luini A, Aguilar M, Marubini E Twenty-year follow-up of a randomized study comparing breast-conserving surgery with radical mastectomy for early breast cancer. N Engl J Med 2002;347:1227-1232.

5 Blichert-Toft M, Smola MG, Cataliotti L, O'Higgins N: Principles and guidelines for surgeons - management of symptomatic breast cancer. On behalf of the European Society of Surgical Oncology. Ann Chir Gynaecol 1998;87:101-109.

-6 Renton SC, Gazet JC, Ford HT, Corbishley C, Sutcliffe R: The importance of the resection margin in conservative surgery for breast cancer. Eur J Surg Oncol 1996;22:17-22.

7 Taghian A, Mohiuddin M, Jagsi R, Goldberg S, Ceilley E, Powell S: Current perceptions regarding surgical margin status after breast-conserving therapy: Results of a survey. Ann Surg 2005;241:629-639.

-8 Lupe K, Truong PT, Alexander C, Lesperance M, Speers C, Tyldesley S: Subsets of women with close or positive margins after breast-conserving surgery with high local recurrence risk despite breast plus boost radiotherapy. Int J Radiat Oncol Biol Phys 2011;81:e561-e568.

9 Park CC, Mitsumori M, Nixon A, Recht A Connolly J, Gelman R, Silver B, Hetelekidis S, Abner A, Harris JR, Schnitt SJ: Outcome at 8 years after breast-conserving surgery and radiation therapy for invasive breast cancer: Influence of margin status and systemic therapy on local recurrence. J Clin Oncol 2000;18:1668-1675.

10 Smitt MC, Nowels K, Carlson RW, Jeffrey SS: Predictors of reexcision findings and recurrence after breast conservation. Int J Radiat Oncol Biol Phys 2003;57:979-985.

11 Luini A, Rososchansky J, Gatti G, Zurrida S, Caldarella P, Viale G, Rosali dos Santos G, Frasson A: The surgical margin status after breastconserving surgery: Discussion of an open issue. Breast Cancer Res Treat 2009;113:397-402. 
12 Revesz E, Khan SA: What are safe margins of resection for invasive and in situ breast cancer? Oncology (Williston Park) 2011;25:890-895.

13 Houssami N, Macaskill P, Marinovich ML, Dixon JM, Irwig L, Brennan ME, Solin LJ: Meta-analysis of the impact of surgical margins on local recurrence in women with early-stage invasive breast cancer treated with breast-conserving therapy. Eur J Cancer 2010;46:3219-3232.

14 Groot G, Rees H, Pahwa P, Kanagaratnam S, Kinloch M: Predicting local recurrence following breast-conserving therapy for early stage breast cancer: The significance of a narrow $(\leq 2 \mathrm{~mm})$ surgical resection margin. J Surg Oncol 2011;103:212216.

15 McCahill LE, Single R, Ratliff J, Sheehey-Jones J, Gray A, James T: Local recurrence after partia mastectomy: Relation to initial surgical margins. Am J Surg 2011;201:374-378; discussion 378.

$\checkmark 16$ Dang CM, Giuliano AE: Local recurrence risk factors in women treated with BCT for earlystage breast cancer. Oncology (Williston Park) 2011;25:895-896, 899.

-17 Scopa CD, Aroukatos P, Tsamandas AC, Aletra C: Evaluation of margin status in lumpectomy specimens and residual breast carcinoma. Breast J 2006; 12:150-153.

-18 Schnitt SJ, Abner A, Gelman R, Connolly JL, Recht A, Duda RB, Eberlein TJ, Mayzel K, Silver B, Harris JR: The relationship between microscopic margins of resection and the risk of local recurrence in patients with breast cancer treated with breast-conserving surgery and radiation therapy. Cancer 1994;74:1746-1751.

19 Mullen R, Macaskill EJ, Khalil A, Elseedawy E, Brown DC, Lee AC, Purdie CA, Jordan LB, Thompson AM: Involved anterior margins after breast conserving surgery: Is re-excision required? Eur J Surg Oncol;38:302-306.

20 Dunne C, Burke JP, Morrow M, Kell MR: Effect of margin status on local recurrence after breast conservation and radiation therapy for ductal carcinoma in situ. J Clin Oncol 2009;27:1615-1620.

21 Wang SY, Chu H, Shamliyan T, Jalal H, Kuntz KM, Kane RL, Virnig BA: Network meta-analysis of margin threshold for women with ductal carcinoma in situ. J Natl Cancer Inst 2012;104:507-516.

22 Kreienberg R, Albert A-S, Follmann M, Kopp I, Kuehn T, Wockel A, Zemmler T: German S3 guideline 'Diagnosis, Therapy, and Follow-up of Breast Cancer', 2012. www.krebsgesellschaft.de/ download/S3_Brustkrebs_Update_2012_OL_ Langversion.pdf

23 Fisher B, Anderson S: Conservative surgery for the management of invasive and noninvasive carcinoma of the breast: NSABP trials. National Surgical Adjuvant Breast and Bowel Project. World J Surg 1994;18:63-69.

-24 Voogd AC, Nielsen M, Peterse JL, Blichert-Toft M, Bartelink H, Overgaard M, van Tienhoven G, Andersen KW, Sylvester RJ, van Dongen JA Differences in risk factors for local and distant recurrence after breast-conserving therapy or mastectomy for stage I and II breast cancer: Pooled results of two large European randomized trials. J Clin Oncol 2001;19:1688-1697.

25 Gerber B, Krause A, Dieterich M, Kundt G, Reimer T: The oncological safety of skin sparing mastectomy with conservation of the nipple-areola complex and autologous reconstruction: An extended follow-up study. Ann Surg 2009;249:461468.

26 Alm El-Din MA, Taghian AG: Breast conservation therapy for patients with locally advanced breast cancer. Semin Radiat Oncol 2009;19:229_ 235.

27 Semiglazov V, Eiermann W, Zambetti M, Manikhas A, Bozhok A, Lluch A, Tjulandin S, Sabadell MD, Caballero A, Valagussa P, Baselga J, Gianni L: Surgery following neoadjuvant therapy in patients with HER2-positive locally advanced or inflammatory breast cancer participating in the neoadjuvant herceptin (NOAH) study. Eur J Surg Oncol 2011;37:856-863.

28 Asoglu O, Muslumanoglu M, Igci A, Ozmen V, Karanlik H, Ayalp K, Bozfakioglu Y, Kecer M, Parlak M: Breast conserving surgery after primary chemotherapy in locally advanced breast cancer. Acta Chir Belg 2005;105:62-68.

29 Garimella V, Qutob O, Fox JN, Long ED, Chaturvedi A, Turnbull LW, Drew PJ: Recurrence rates after DCE-MRI image guided planning for breast-conserving surgery following neoadjuvant chemotherapy for locally advanced breast cancer patients. Eur J Surg Oncol 2007;33:157-161.

30 Lee S, Kim SW, Kim SK, Lee KS, Kim EA, Kwon Y, Shin KH, Kang HS, Ro J, Lee ES: Locoregional recurrence of breast conserving surgery after preoperative chemotherapy in Korean women with locally advanced breast cancer. J Breast Cancer 2011;14:289-295.

31 Dawood S, Merajver SD, Viens P, Vermeulen PB, Swain SM, Buchholz TA, Dirix LY, Levine PH, Lucci A, Krishnamurthy S, Robertson FM, Woodward WA, Yang WT, Ueno NT, Cristofanilli M: International expert panel on inflammatory breast cancer: consensus statement for standardized diagnosis and treatment. Ann Oncol;22:515-523.

32 Kuehn T, Bembenek A, Decker T, Munz DL, Sautter-Bihl ML, Untch M, Wallwiener D: A concept for the clinical implementation of sentinel lymph node biopsy in patients with breast carcinoma with special regard to quality assurance. Cancer 2005;103:451-461.

33 Lyman GH, Giuliano AE, Somerfield MR, Benson AB 3rd, Bodurka DC, Burstein HJ, Cochran AJ, Cody HS 3rd, Edge SB, Galper S, Hayman JA, Kim TY, Perkins CL, Podoloff DA, Sivasubramaniam VH, Turner RR, Wahl R, 'Weaver DL, Wolff AC, Winer EP: American Society of Clinical Oncology guideline recommendations for sentinel lymph node biopsy in early-stage breast cancer. J Clin Oncol 2005;23:7703-7720.

34 Veronesi U, Paganelli G, Viale G, Luini A, Zurrida S, Galimberti V, Intra M, Veronesi P, Robertson C, Maisonneuve P, Renne G, De Cicco C, De Lucia F: A randomized comparison of sentinelnode biopsy with routine axillary dissection in breast cancer. N Engl J Med 2003;349:546-553.

35 Krag DN, Anderson SJ, Julian TB, Brown AM, Harlow SP, Costantino JP, Ashikaga T, Weaver DL, Mamounas EP, Jalovec LM, Frazier TG, Noyes RD, Robidous A, Scarth HM, Wolmark N: Sentinellymph-node resection compared with conventional axillary-lymph-node dissection in clinically nodenegative patients with breast cancer: overall survival findings from the NSABP B-32 randomised phase 3 trial. Lancet Oncol 2012;11:927-33.

36 NZGG 2009.

37 Palesty JA, Foster JM, Hurd TC, Watroba N, Rezaishiraz H, Edge SB: Axillary recurrence in women with a negative sentinel lymph node and no axillary dissection in breast cancer. J Surg Oncol 2006;93:129-132.

38 Smidt ML, Janssen CM, Kuster DM, Bruggink ED, Strobbe LJ: Axillary recurrence after a negative sentinel node biopsy for breast cancer: Incidence and clinical significance. Ann Surg Oncol 2005;12: 29-33.

39 Veronesi U, Galimberti V, Mariani L, Gatti G, Paganelli G, Viale G, Zurrida S, Veronesi P, Intra M, Gennari R, Rita Vento A, Luini A, Tullii M, Bassani G, Rotmensz N: Sentinel node biopsy in breast cancer: Early results in 953 patients with negative sentinel node biopsy and no axillary dissection. Eur J Cancer 2005;41:231-237.

40 Zavagno G, Carcoforo P, Franchini Z, Renier M, Barutta L, De Salvo GL, Maravegias K, Capitanio G, Nitti D, Lise M: Axillary recurrence after negative sentinel lymph node biopsy without axillary dissection: A study on 479 breast cancer patients. Eur J Surg Oncol 2005;31:715-720.

41 Mansel RE, Fallowfield L, Kissin M, Goyal A, Newcombe RG, Dixon JM, Yiangou C, Horgan K, Bundred N, Monypenny I, England D, Sibbering M Abdullah TI, Barr L, Chetty U, Sinnett DH, Fleissig A, Clarke D, Ell PJ: Randomized multicenter trial of sentinel node biopsy versus standard axillary treatment in operable breast cancer: The ALMANAC trial. J Natl Cancer Inst 2006;98:599_ 609.

42 Fleissig A, Fallowfield LJ, Langridge CI, Johnson L, Newcombe RG, Dixon JM, Kissin M, Mansel RE: Post-operative arm morbidity and quality of life. Results of the ALMANAC randomised trial comparing sentinel node biopsy with standard axillary treatment in the management of patients with early breast cancer. Breast Cancer Res Treat 2006;95:279-293.

43 Bauerfeind I: Stellenwert der Sentinel-NodeBiopsie im Rahmen neoadjuvanter Therapiekonzepte beim Mammakarzinom: Überblick und aktuelles Studienkonzept. Geburtshilfe und Frauenheilkd 2007;67:22.

44 Borgstein PJ, Meijer S, Pijpers RJ, van Diest PJ: Functional lymphatic anatomy for sentinel node biopsy in breast cancer: Echoes from the past and the periareolar blue method. Ann Surg 2000; 232:81-89.

45 Ferrari A, Dionigi P, Rovera F, Boni L, Limonta G, Garancini S, De Palma D, Dionigi G, Vanoli C, Diurni M, Carcano G, Dionigi R: Multifocality and multicentricity are not contraindications for sentinel lymph node biopsy in breast cancer surgery. World J Surg Oncol 2006;4:79.

46 Gentilini O, Trifiro G, Soteldo J, Luini A, Intra M, Galimberti V, Veronesi P, Silva L, Gandini S, Paganelli G, Veronesi U: Sentinel lymph node biopsy in multicentric breast cancer. The experience of the European Institute of Oncology. Eur J Surg Oncol 2006;32:507-510.

47 Knauer M, Konstantiniuk P, Haid A, Wenzl E, Riegler-Keil M, Postlberger S, Reitsamer R, Schrenk P: Multicentric breast cancer: A new indication for sentinel node biopsy - a multi-institutional validation study. J Clin Oncol 2006;24:3374 3380

48 Giuliano AE, Hunt KK, Ballman KV, Beitsch PD, Whitworth PW, Blumencranz PW, Leitch AM, Saha S, McCall LM, Morrow M: Axillary dissection vs no axillary dissection in women with invasive breast cancer and sentinel node metastasis: A randomized clinical trial. JAMA 2011;305:569-575.

49 Veronesi U, Orecchia R, Zurrida S, Galimberti V, Luini A, Veronesi P, Gatti G, D'Aiuto G, Cataliotti L, Paolucci R, Piccolo P, Massaioli N, Sismondi P, Rulli A, Lo Sardo F, Recalcati A Terribile D, Acerbi A, Rotmensz N, Maisonneuve P: Avoiding axillary dissection in breast cancer surgery: A randomized trial to assess the role of axillary radiotherapy. Ann Oncol 2005;16:383-388. 
50 Goldhirsch A, Wood WC, Gelber RD, Coates AS, Thurlimann B, Senn HJ: Meeting highlights: Updated international expert consensus on the primary therapy of early breast cancer. J Clin Oncol 2003;21:3357-3365.

-51 Louis-Sylvestre C, Clough K, Asselain B, Vilcoq JR, Salmon RJ, Campana F, Fourquet A: Axillary treatment in conservative management of operable breast cancer: Dissection or radiotherapy? Results of a randomized study with 15 years of follow-up. J Clin Oncol 2004;22:97-101.

52 Fisher B, Jeong JH, Anderson S, Bryant J, Fisher ER, Wolmark N: Twenty-five-year follow-up of a randomized trial comparing radical mastectomy, total mastectomy, and total mastectomy followed by irradiation. N Engl J Med 2002;347:567-575.

53 Rudenstam CM, Zahrieh D, Forbes JF, Crivellari D, Holmberg SB, Rey P, Dent D, Campbell I, Bernhard J, Price KN, Castiglione-Gertsch M, Goldhirsch A, Gelber RD, Coates AS: Randomized trial comparing axillary clearance versus no axillary clearance in older patients with breast cancer: First results of International Breast Cancer Study Group Trial 10-93. J Clin Oncol 2006;24:337-344.

54 Christiaens M, Vlayen J, Gailly J: Scientific support of the College of Oncology: a national clinical practice guideline for breast cancer. KCE Report 63A. Brussel, Belgian Health Care Knowledge Centre (KCE), 2007.

-55 Kuehn T, Bembenek A, Decker T, Munz DL, Sautter-Bihl ML, Untch M, Wallwiener D: A concept for the clinical implementation of sentinel lymph node biopsy in patients with breast carcinoma with special regard to quality assurance. Cancer 2005;103:451-61.

56 NICE. National Institute for Clinical Excellence (NICE): Early and locally advanced breast cancer. Diagnosis and treatment 2009.

57 Menes TS, Tartter PI, Bleiweiss I, Godbold JH, Estabrook A, Smith SR: The consequence of multiple re-excisions to obtain clear lumpectomy margins in breast cancer patients. Ann Surg Oncol 2005;12:881-885.

-58 Petit JY, Veronesi U, Orecchia R, Curigliano G, Rey PC, Botteri E, Rotmensz N, Lohsiriwat V, Cassilha Kneubil M, Rietjens M: Risk factors associated with recurrence after nipple-sparing mastectomy for invasive and intraepithelial neoplasia. Ann Oncol 2012;23:2053-2058.

59 Liukkonen S, Leidenius M, Saarto T, SjostromMattson J: Breast cancer in very young women. Eur J Surg Oncol 2011;37:1030-1037.

60 Rapiti E, Fioretta G, Verkooijen HM, Vlastos G, Schafer P, Sappino AP, Kurtz J, Neyroud-Caspar I, Bouchardy C: Survival of young and older breast cancer patients in Geneva from 1990 to 2001. Eur J Cancer 2005;41:1446-1452.
61 Anders CK, Hsu DS, Broadwater G, Acharya CR, Foekens JA, Zhang Y, Wang Y, Marcom PK, Marks JR, Febbo PG, Nevins JR, Potti A, Blackwell KL: Young age at diagnosis correlates with worse prognosis and defines a subset of breast cancers with shared patterns of gene expression. J Clin Oncol 2008;26:3324-3330.

62 Kim HJ, Han W, Yi OV, Shin HC, Ahn SK, Koh BS, Moon HG, You JH, Son BH, Ahn SH, Noh DY: Young age is associated with ipsilateral breast tumor recurrence after breast conserving surgery and radiation therapy in patients with HER2-positive/ER-negative subtype. Breast Cancer Res Treat 2011;130:499-505.

63 Biganzoli L, Wildiers H, Oakman C, Marotti L, Loibl S, Kunkler I, Reed M, Ciatto S, Voogd AC, Brain E, Cutuli B, Terret C, Gosney M, Aapro M, Audisio R: Management of elderly patients with breast cancer: Updated recommendations of the International Society of Geriatric Oncology (SIOG) and European Society of Breast Cancer Specialists (EUSOMA). Lancet Oncol 2012; 13:e148-e160.

64 Giordano SH, Hortobagyi GN, Kau SW, Theriault RL, Bondy ML: Breast cancer treatment guidelines in older women. J Clin Oncol 2005;23:783-791.

65 Mustacchi G, Cazzaniga ME, Pronzato P, De Matteis A, Di Costanzo F, Floriani I: Breast cancer in elderly women: A different reality? Results from the NORA study. Ann Oncol 2007; 18:991-996.

66 Enger SM, Thwin SS, Buist DS, Field T, Frost F, Geiger AM, Lash TL, Prout M, Yood MU, Wei F, Silliman RA: Breast cancer treatment of older women in integrated health care settings. J Clin Oncol 2006;24:4377-4383.

67 Bouchardy C, Rapiti E, Fioretta G, Laissue P, Neyroud-Caspar I, Schafer P, Kurtz J, Sappino AP, Vlastos G: Undertreatment strongly decreases prognosis of breast cancer in elderly women. J Clin Oncol 2003;21:3580-3587.

68 Hind D, Wyld L, Reed MW: Surgery, with or without tamoxifen, vs tamoxifen alone for older women with operable breast cancer: Cochrane review. Br J Cancer 2007;96:1025-1029.

69 Martelli G, Miceli R, Daidone MG, Vetrella G, Cerrotta AM, Piromalli D, Agresti R: Axillary dissection versus no axillary dissection in elderly patients with breast cancer and no palpable axillary nodes: Results after 15 years of follow-up. Ann Surg Oncol 2011;18:125-133.

70 Antoniou A, Pharoah PD, Narod S, Risch HA, Eyfjord JE, Hopper JL, Loman N, Olsson H, Johannsson O, Borg A, Pasini B, Radice P, Manoukian S, Eccles DM, Tang N, Olah E, AntonCulver H, Warner E, Lubinski J, Gronwald J, Gorski B, Tulinius H, Thorlacius S, Eerola H, Nevanlinna H, Syrjakoski K, Kallioniemi OP,
Thompson D, Evans C, Peto J, Lalloo F, Evans DG, Easton DF: Average risks of breast and ovarian cancer associated with BRCA1 or BRCA2 mutations detected in case series unselected for family history: A combined analysis of 22 studies. Am J Hum Genet 2003;72:1117-1130.

71 Goldberg JI, Borgen PI: Breast cancer susceptibility testing: Past, present and future. Expert Rev Anticancer Ther 2006;6:1205-1214.

72 Metcalfe K, Lynch HT, Ghadirian P, Tung N, Olivotto I, Warner E, Olopade OI, Eisen A, Weber B, McLennan J, Sun P, Foulkes WD, Narod SA: Contralateral breast cancer in BRCA1 and BRCA2 mutation carriers. J Clin Oncol 2004;22:2328-2335.

73 Robson M, Svahn T, McCormick B, Borgen P, Hudis CA, Norton L, Offit K: Appropriateness of breast-conserving treatment of breast carcinoma in women with germline mutations in BRCA1 or BRCA2: A clinic-based series. Cancer 2005;103: 44-51.

74 Hartmann LC, Sellers TA, Schaid DJ, Frank TS, Soderberg CL, Sitta DL, Frost MH, Grant CS, Donohue JH, Woods JE, McDonnell SK, Vockley CW, Deffenbaugh A, Couch FJ, Jenkins RB: Efficacy of bilateral prophylactic mastectomy in BRCA1 and BRCA2 gene mutation carriers. J Natl Cancer Inst 2001;93:1633-1637.

75 Meijers-Heijboer H, van Geel B, van Putten WL, Henzen-Logmans SC, Seynaeve C, MenkePluymers MB, Bartels CC, Verhoog LC, van den Ouweland AM, Niermeijer MF, Brekelmans CT, Klijn JG: Breast cancer after prophylactic bilateral mastectomy in women with a BRCA1 or BRCA2 mutation. N Engl J Med 2001;345:159-164.

76 Rebbeck TR, Friebel T, Lynch HT, Neuhausen SL, van 't Veer L, Garber JE, Evans GR, Narod SA, Isaacs C, Matloff E, Daly MB, Olopade OI, Weber BL: Bilateral prophylactic mastectomy reduces breast cancer risk in BRCA1 and BRCA2 mutation carriers: The prose study group. J Clin Oncol 2004;22:1055-1062.

77 Metcalfe KA, Lynch HT, Ghadirian P, Tung N, Olivotto IA, Foulkes WD, Warner E, Olopade O, Eisen A, Weber B, McLennan J, Sun P, Narod SA: The risk of ovarian cancer after breast cancer in BRCA1 and BRCA2 carriers. Gynecol Oncol 2005;96:222-226.

78 van Sprundel TC, Schmidt MK, Rookus MA, Brohet R, van Asperen CJ, Rutgers EJ, Van't Veer LJ, Tollenaar RA: Risk reduction of contralateral breast cancer and survival after contralateral prophylactic mastectomy in BRCA1 or BRCA2 mutation carriers. Br J Cancer 2005;93:287-292. 